Zusammenfassung. Die Insuffizienz der oesophagojejunalen Anastomose nach Gastrektomie ist eine der häufigsten Komplikationen mit hoher Letalität. Als Ursache sind u. a. hauptsächlich operationstechnische Schwierigkeiten und Fehler anzuführen. Nach insgesamt 539 Gastrektomien kam es 55 mal zur proximalen Nahtinsuffizienz, die in 38,2\% letal verlief. Seit Durchführung der Gastrektomie „de principe“ konnte sowohl die postoperative Letalität wie auch die Frequenz der tödlichen Nahtinsuffizienzen deutlich gesenkt werden ( 20,6 bzw. $75 \%$ auf $9,3 \%$ bzw. $35,3 \%$ ). Vorteilhaft erwies sich die Anlage einer proximalen End/SeitAanastomose bei der Jejunuminterposition oder der Roux-Schlinge. Prävention dieser Komplikation nach Gastrektomie kommt entscheidende Bedeutung zu.

Schliisselwörter: Maligne Magentumoren - Gastrektomie - proximale Nahtinsuffizienz.

\title{
248. Die Y-Roux-Rekonstruktion nach Gastrektomie: Ein adäquates Rekonstruktionsverfahren?
}

\author{
L. Lehmann, P. Klaue, A. Kroiss, W. Düsel, Chr. Eilers und W. Gerhart \\ Chirurgische Universitätsklinik Würzburg, Abteilung für Nuklearmedizin der Universität Würzburg, \\ Josef-Schneider-Straße 2, D-8700 Würzburg
}

\section{Roux-en-Y Procedures After Gastrectomy. An Effective Procedure?}

\begin{abstract}
Summary. Among the 73 patients who underwent gastrectomy and a Roux-en-Y procedure using a $60-\mathrm{cm}$ jejunal segment the mortality was $9.7 \%$. Anastomotic leaks were demonstrated radiologically in $6.8 \%$ and clinically evident in $4.1 \%$. Of the patients followed up for 3 months $95.5 \%$ were symptom-free. Oesophagitis was histologically present in $4.5 \%$ of the patients with macroscopically intact mucosa. Postoperative reflux scintillation scans showed no reflux in any of the patients (pre-operative $10 \%$ ) and revealed a stimulated biliary reflux in $16.6 \%$ (pre-operative $55 \%$ ).
\end{abstract}

Key words: Gastrectomy - Reflux oesophagitis - Reflux scintillation scans.

Zusammenfassung. Die Letalität nach 73 Gastrektomien und Rekonstruktion mit einer $60 \mathrm{~cm}$ langen ausgeschalteten Jejunalschlinge betrug insgesamt $9,7 \%$, eine Anastomoseninsuffizienz trat röntgenologisch in $6,8 \%$, klinisch in 4,1\% auf. 95,5\% der nach 3 Monaten nachuntersuchten Patienten waren beschwerdefrei. In 4,5\% fand sich histologisch bei makroskopisch intakter Oesophagusschleimhaut eine Oesophagitis. Bei der Refluxszintigraphie konnte postoperativ bei keinem (präoperativ $10 \%$ ) der Patienten ein Nüchternreflux, in $16,6 \%$ (präoperativ $55 \%$ ) ein stimulierter biliärer Reflux beobachtet werden.

Schlïsselwörter: Gastrektomie - Refluxoesophagitis - Refluxszintigraphie.

\section{Funktionelle Ergebnisse verschiedener Operationsverfahren der totalen Gastrektomie}

\author{
P. Carabalona, H. Amberger und J. P. Carabalona \\ Chirurgische Universitätsklinik, F-34000 Montpellier
}

\section{Functional Results of Different Surgical Procedures in Total Gastrectomy}

Summary. A total of 1676 patients who had total gastrectomies by different surgical procedures were checked up for the following parameters: reflux, dumping syndrome, diarrhoea, weight loss over $5 \mathrm{~kg}$. We compared the results of seven different procedures. Independent of the surgical technique, operative mortality $(10 \%-12 \%)$ and rate of leakage $(8 \%-12 \%$ were comparable. Conclusions: (1) The Roux procedure seems to be the most advantageous as regards reflux $(18 \%)$ and dumping syndrome $(18 \%)$. (2) Jejunum interposition gives the best functional results. (3) Reconstruction of the reservoir function is possible with the seven procedures described.

Key words: Long-term results - Total gastrectomy.

Zusammenfassung. 1676 Patienten, bei denen nach verschiedenen OP-Verfahren der Magenersatz nach totaler Gastrektomie durchgeführt wurde, wurden auf folgende Parameter untersucht: Reflux, Dumping-Syndrom, 